\title{
Mexiletine as one effective alternative for antiarrhythmic drugs and ablation resistant electrical storm - A case report
}

\author{
Martyna Zaleskaa , Maria Różańskaa , Olga Możeńskaa, Dariusz Artur Kosior ${ }^{b}$ \\ a Department of Cardiology and Hypertension, Central Research Hospital, The Ministry of the Interior, Woloska 137, \\ 02-507 Warsaw, Poland \\ ${ }^{b}$ Department of Applied Physiology, Mossakowski Medical Research Centre, Polish Academy of Sciences, \\ Pawińskiego 5, 02-106 Warsaw, Poland
}

\section{ARTICLE INFO}

\section{Article history:}

Received: 29. 12. 2016

Received in revised form:

19. 6. 2017

Accepted: 21. 6. 2017

Available online: 26. 7. 2017

Klíčová slova:

Ablace

Implantabilní

kardioverter-defibrilátor

Komorové arytmie

Mexiletin

Srdeční selhání

\section{SOUHRN}

Popisujeme př́pad 78letého muže, který byl převezen na naše oddělení pro četné epizody maligních komorových arytmií neodpovídajících na předchozí antiarytmickou léčbu (optimalizace nastavení zařízení, podávání amiodaronu, infuze lidokainu a optimální farmakoterapie). Pacient byl navíc v terminálním stadiu srdečního selhání ischemické etiologie a měl implantován CRT-D. Po vyloučení sekundárních příčin elektrické bouře a vzhledem k neúčinnosti farmakoterapie jsme přistoupili k radiofrekvenční ablaci. První den po výkonu došlo k recidivě život ohrožujících komorových tachykardií/fibrilací komor. Jako poslední možnost jsme upravili léčbu a začali pacientovi podávat mexiletin s následným úplným vymizením komplexních komorových arytmií. Při neúčinné léčbě amiodaronem může mexiletin představovat účinné alternativní antiarytmikum.

○ 2017, ČKS. Published by Elsevier Sp. z o.o. All rights reserved.

\section{ABSTRACT}

We present case of 78-year-old male transferred to our Department due to multiple episodes of malignant ventricular arrhythmias refractory to previous antiarrhythmic treatments (device settings optimization, amiodarone treatment, lidocaine infusion and optimal pharmacotherapy). Additionally, patient had ischemic end-stage heart failure and implanted CRT-D. We excluded secondary causes of electrical storm and due to inefficacy of medical therapy, we applied radiofrequency ablation. During 1st day after procedure life-threatening VT/VF recurred. As our last choice, we modified therapy and introduced mexiletine, what resulted in complete disappearance of complex ventricular arrhythmias.

In case of amiodarone inefficacy mexiletine may be considered effective alternative antiarrhythmic drug. 


\section{Introduction}

Electrical storm (ES) is a state of cardiac electrical instability. Typically, it affects older men with coronary artery disease [1]. Amiodarone plus $\beta$-blocker is the most effective therapy to prevent ventricular tachycardia (VT) or ventricular fibrillation (VF) in patients with implanted cardioverter-defibrillator (ICD) [2]. However, while inefficient, alternative medications and methods might to be considered. We present a case of 78-year-old male patient in whom we managed to successfully use one of such alternative medications - mexiletine.

\section{Case report}

We present a case of 78-year-old male transferred to Department of Cardiology due to multiple episodes of malignant ventricular arrhythmias refractory to previous antiarrhythmic treatments including device settings optimization, antiarrhythmic drug therapy (amiodarone, lidocaine) and optimal pharmacotherapy. The patient had history of biventricular, end-stage heart failure (HF) due to ischemic dilated cardiomyopathy, enlarged left ventricle up to $78 \mathrm{~mm}$ in diastole and systolic dysfunction with ejection fraction (LVEF) 15\%, apex aneurysm with thrombus, permanent atrial fibrillation, third-degree atrioventricular block, hypertension, diabetes mellitus type 2 and chronic kidney disease. He underwent inferior wall myocardial infarction 24 years ago that was treated conservatively and primary PCl with stent implantation in the left anterior descending artery complicated by sudden cardiac arrest 8 years ago. Eight years earlier patient underwent ICD implantation (as the secondary prevention of sudden cardiac death [SCD]), which was followed by upgrade to cardiac resynchronization therapy-defibrillator (CRT-D) 4 years later.

Before transfer to our Department the patient was hospitalized due to infectious exacerbation of congestive HF (CHF). Prior to ES initiation for couple of weeks patient suffered from respiratory tract infection, refractory to different courses of antibiotics. Sustaining elevation of infectious parameters clinically resulted in CHF exacerbation, what led to ES. During previous hospitalizations, multiple unsuccessful attempts to modify CRT-D settings were made, i.e. higher-rate detection threshold of VT, VT overriding, different antitachycardia pacing (ATP) algorithms or when unsuccessful or hemodynamically unstable ICD-initiated cardioversions. To achieve stabilization of the general state, the patient required continuous amiodarone administration and intravenous lidocaine infusion.

In our Department, we observed hemodynamically unstable cardiac arrhythmias - monomorphic, degenerating to polymorphic VT and VF (Fig. 1A) resulting in CRT-D interventions up to several dozen a day. Laboratory data were as follows: red blood cells $-4.73 \times 10^{6} / \mu \mathrm{L}$; hemoglobin - $14.2 \mathrm{~g} / \mathrm{dL}$; white blood cells - $12.81 \times 10^{3} / \mu \mathrm{L}$; estimated glomerular filtration rate $-38 \mathrm{ml} / \mathrm{min} / 1.72 \mathrm{~m}^{2}$; creatinine $-1.76 \mathrm{mg} / \mathrm{dL}$; C-reactive protein $-52.2 \mathrm{mg} / \mathrm{L}$; D-dimers - $2732 \mathrm{pg} / \mathrm{ml}$; platelets - $188 \times 10^{3} / \mu \mathrm{L}$; NT-proBNP value - $5711 \mu \mathrm{g} / \mathrm{L}$; INR - 1.76; creatinine kinase (CK) - 52 IU/L; CK MB isoenzyme - 24 IU/L; troponin I - $0.063 \mathrm{IU} / \mathrm{L}$. Potassium and magnesium level on admission were 4.6 $\mathrm{mmol} / \mathrm{L}$ and $1.1 \mathrm{mmol} / \mathrm{L}$, respectively. Initial corrected QT interval (QTC) was $430 \mathrm{~ms}$. Due to elevated inflammation parameters, antibiotic therapy was continued. Before transfer to our Department the patient received amoxicillin with clavulanic acid (which do not prolong QTC). We switched the therapy to clarithromycin with ciprofloxacin. Additionally, optimal pharmacotherapy for $\mathrm{CHF}$ exacerbation, including angiotensin II receptor blocker, -blocker, statin, spironolactone and furosemide in maximal tolerated doses, was continued.

Cardiac arrhythmias were refractory to antiarrhythmic drugs and caused further deterioration of patient's clinical status. On the 3rd day in our Department we tried to ablate VT, which originated from LV (Fig. 1B). Before and during the procedure the patient received vancomycin, as prophylaxis. Programmed ventricular stimulation induced monomorphic VT, cycle length $430 \mathrm{~ms}$ with alternans. There were 2 dominating PVC morphologies and they were considered the ablation's target. After procedure programmed ventricular stimulation did not induce VT. Early post-procedure period was uneventful. On the 1st day after intervention we observed aggravation of life-threating, hemodynamically unstable, cardiac arrhythmias. Patient received additionally amiodarone p.o., continuous i.v. infusion of midazolam and xylocaine in up-titrated doses. We withdrew metoprolol and introduced carvedilol and gave fractioned s.c. doses of morphine.
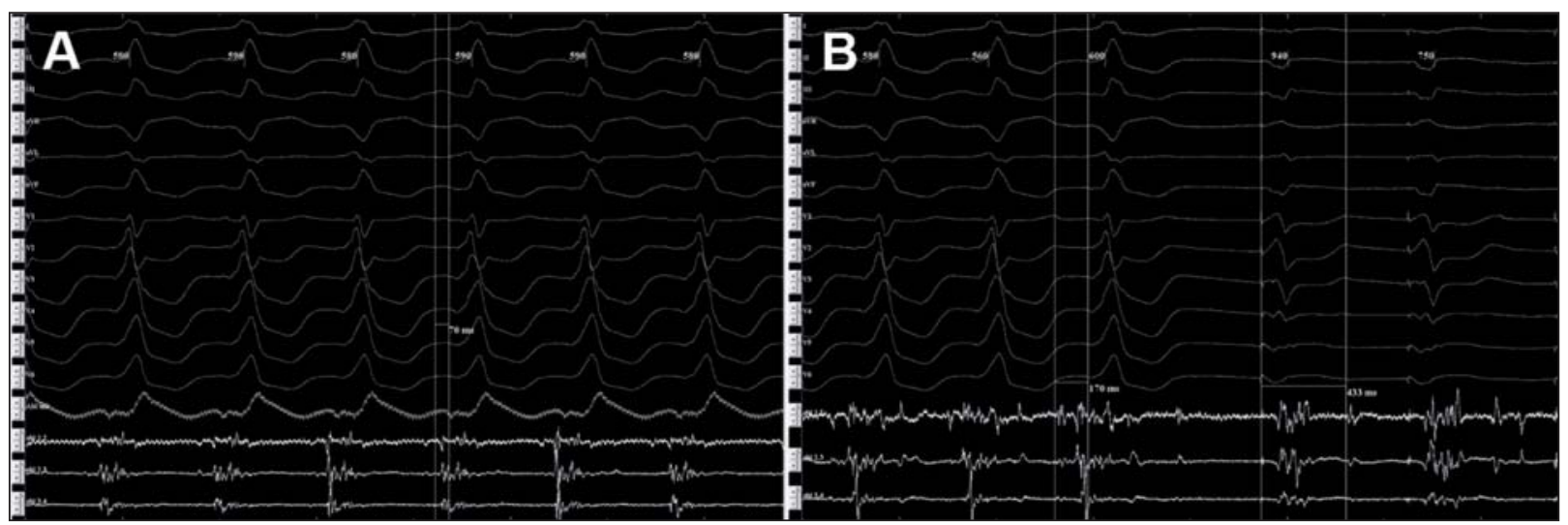

Fig. 1 - Monomorphic ventricular tachycardia before ablation; (B) attempt at ablation substrate of ventricular tachycardia. 
Additionally, we made temporary attempt to inactivate ATP. Due to Clostridium difficile infection the antibiotic therapy was switched one more time - to vancomycin p.o.

Four days after radio-frequency ablation due to sustaining life-threatening condition we decided to withdraw amiodarone (QTC $=420 \mathrm{~ms}$ ) and introduced therapy with mexiletine. The initial dose was $400 \mathrm{mg}$ 3-times per day and was up-titrated up to $400 \mathrm{mg}$ 4-times per day. After mexiletine administration we did not observe any complex cardiac arrhythmias. We noted gradual stabilization and improvement of patient's general clinical status.

\section{Discussion}

Electrical storm is common in ICD patients, occurring in about $7 \%$ of them, which is significantly more frequent than in CRT-D patients (about 0.6\%) [3]. However, some other studies show the ES occurrence in patients with CRT-D of about 7\% [4]. The ES risk factors include: low LVEF, device implantation in the secondary SCD prevention and age over 65 [3-5]. All of them were present in our patient. In our case ES was in a shape of recurring preserved monomorphic VTs, caused by single premature ventricular contractions (PVCs), degenerating to polymorphic VTs and VF due to antiarrhythmic stimulation. All of them required multiple interventions, from both CRT-D and external defibrillator. The fact that CRT-D may trigger monomorphic and polymorphic VT was reported in the literature [6-10]. Izquierdo et al. showed that in patients with ES there was no difference, in neither survival nor ES recurrence in over 2 years follow-up after an episode of ES, between ablation and conservative treatment. They also showed that poor LVEF was associated with higher recurrence of ES in patients who underwent ablation [11]. Nayak et al. showed that the best way to manage monomorphic VT in CRT-D patients suffering from ES, was to either ablate arrhythmic substrate, or to turn off LV pacing and then introduce long-term antiarrhythmic pharmacological therapy [12]. According to the latest guidelines urgent catheter ablation is indicated in patients with scar-related heart disease presenting with ES [13]. We took all of the above data under consideration and went on with ablation as our first choice. Recently Murata et al. reported incidence of amiodarone-refractory ES of $30 \%$ and at the same time Gao et al. showed that in case of amiodarone inefficacy, introduction of mexiletine reduced number of VT or VF events in ICD patients (although mexiletine-therapy in long-term follow-up did not reduce number of shocks) $[14,15]$. Although small cardiodepressant effect after mexiletine administration in patients with HF was described, data are inconclusive $[16,17]$. It may be associated with impaired mexiletine clearance in patients with HF [18]. The reason why mexiletine might be efficient may be that it blocks sodium channels. That might reduce number of PVC originating from Purkinje network [19]. Mexiletine may also influence proarrhythmic effects of class III agents due to downscaling of QT-prolonging effects [19]. Moreover, cardioprotective effect of mexiletine was also described. It might be due to opening of adenosine triphosphate-sensitive potassium channels, thus preventing calcium overload and leading to protection against both ischemia- and reperfusion-injury [20].

Although ICD and CRT-D implantations are life-saving therapies, used widely as prevention of SCD, they could also trigger cardiac arrhythmias, including ES. Amiodarone - the most widely used antiarrhythmic drug - sometimes proves inefficient and then other medications should be considered. Mexiletine, with its described cardioprotective properties, seems to be beneficial alternative for patients with recurrent ES refractory to other therapies, including ablation, as shown in our case. It might be also considered safe in some patients with severely impaired LVEF.

\section{Conflict of interest}

The authors declare that they have no conflict of interest.

\section{Funding body}

None.

\section{Ethical statement}

Authors state that the research was conducted according to ethical standards.

\section{Informed consent}

I declare that informed consent to publish the results was given by all the patients.

\section{Appendix A. Supplementary data}

Supplementary data associated with this article can be found, in the online version, at doi:10.1016/j.crvasa.2017.06.011.

\section{References}

[1] P.R. Kowey, An overview of antiarrhythmic drug management of electrical storm, Canadian Journal of Cardiology 12 (Suppl. B) (1996) 3B-8B, discussion 27B-28B.

[2] S.J. Connolly, P. Dorian, R.S. Roberts, et al., Comparison of $\beta$-blockers, amiodarone plus $\beta$-blockers, or sotalol for prevention of shocks from implantable cardioverter defibrillators: the OPTIC study: a randomized trial, Journal of the American Medical Association 295 (2006) 165-171.

[3] P. Nordbeck, B. Seidl, B. Fey, et al., Effect of cardiac resynchronization therapy on the incidence of electrical storm, International Journal of Cardiology 143 (2010) 330-336.

[4] M. Gasparini, M. Lunati, M. Landolina, et al., Electrical storm in patients with biventricular implantable cardioverter defibrillator: incidence, predictors, and prognostic implications, American Heart Journal 156 (2008) 847-854

[5] F. Streitner, J. Kuschyk, C. Veltmann, et al., Predictors of electrical storm recurrences in patients with implantable cardioverter-defibrillators, Europace 13 (2011) 668-674.

[6] J.M. Guerra, J. Wu, J.M. Miller, W.J. Groh, Increase in ventricular tachycardia frequency after biventricular implantable cardioverter defibrillator upgrade, Journal of Cardiovascular Electrophysiology 14 (2003) 1245-1247.

[7] V.A. Medina-Ravell, R.S. Lankipalli, G.X. Yan, et al., Effect of epicardial or biventricular pacing to prolong QT interval and increase transmural dispersion of repolarization: does resynchronization therapy pose a risk for patients predisposed to long QT or torsade de pointes? Circulation 107 (2003) 740-746.

[8] A. Di Cori, M.G. Bongiorni, G. Arena, et al., New-onset ventricular tachycardia after cardiac resynchronization therapy, Journal of Interventional Cardiac Electrophysiology 12 (2005) 231-235. 
[9] A. Mykytsey, P. Maheshwari, G. Dhar, et al., Ventricular tachycardia induced by biventricular pacing in patient with severe ischemic cardiomyopathy, Journal of Cardiovascular Electrophysiology 16 (2005) 655-658.

[10] B.K. Kantharia, J.A. Patel, B.S. Nagra, et al., Electrical storm of monomorphic ventricular tachycardia after a cardiacresynchronization-therapy-defibrillator upgrade, Europace 8 (2006) 625-628

[11] M. Izquierdo, R. Ruiz-Granell, A. Ferrero, et al., Ablation or conservative management of electrical storm due to monomorphic ventricular tachycardia: differences in outcome, Europace 14 (2012) 1734-1739.

[12] H.M. Nayak, R.J. Verdino, A.M. Russo, et al., Ventricular tachycardia storm after initiation of biventricular pacing: incidence, clinical characteristics, management, and outcome, Journal of Cardiovascular Electrophysiology 19 (2008) 708-715.

[13] S.G. Priori, C. Blomstrom-Lundqvist, A. Mazzanti, et al., 2015 ESC Guidelines for the management of patients with ventricular arrhythmias and the prevention of sudden cardiac death: the Task Force for the Management of Patients with Ventricular Arrhythmias and the Prevention of Sudden Cardiac Death of the European Society of Cardiology (ESC). Endorsed by: Association for European Paediatric and Congenital Cardiology (AEPC), European Heart Journal 36 (2015) 2793 2867.

[14] H. Murata, Y. Miyauchi, M. Hayashi, et al., Clinical and electrocardiographic characteristics of electrical storms due to monomorphic ventricular tachycardia refractory to intravenous amiodarone, Circulation Journal 79 (2015) 2130-2137.

[15] D. Gao, H. Van Herendael, L. Alshengeiti, et al., Mexiletine as an adjunctive therapy to amiodarone reduces the frequency of ventricular tachyarrhythmia events in patients with an implantable defibrillator, Journal of Cardiovascular Pharmacology 62 (2013) 199-204.

[16] H. Morita, K. Hirabayashi, S. Nozaki, et al., Chronic effect of oral mexiletine administration on left ventricular contractility in patients with congestive heart failure: a study based on mitral regurgitant flow velocity measured by continuous-wave Doppler echocardiography, Journal of Clinical Pharmacology 35 (1995) 478-483.

[17] S.S. Gottlieb, M. Weinberg, Cardiodepressant effects of mexiletine in patients with severe left ventricular dysfunction, European Heart Journal 13 (1992) 22-27.

[18] M. Kobayashi, K. Fukumoto, K. Ueno, Effect of congestive heart failure on mexiletine pharmacokinetics in a Japanese population, Biological \& Pharmaceutical Bulletin 29 (2006) 2267-2269.

[19] D. Fedida, P.M. Orth, J.C. Hesketh, et al., The role of late I and antiarrhythmic drugs in EAD formation and termination in Purkinje fibers, Journal of Cardiovascular Electrophysiology 17 (Suppl. 1) (2006) S71-S78.

[20] K. Inuo, S. Niwano, Y. Morohoshi, et al., Cardioprotective effect of mexiletine in acute myocardial ischemia. Studies in the rabbit closed chest ischemia model, Circulation Journal 66 (2002) 403-410. 